\title{
GAMBARAN PROSES PUTUS CINTA PADA WANITA DEWASA MUDA DI JAKARTA: SEBUAH STUDI KASUS
}

\author{
Pingkan C. B. Rumondor \\ Psychology Department, Faculty of Humanities, BINUS University \\ Jln. Kemanggisan Ilir III No. 45, Kemanggisan-Palmerah, Jakarta Barat 11480 \\ pingkan_rumondor@binus.ac.id
}

\begin{abstract}
The end of an intimate relationship is a common incident in pre-marital young adult relationship. Hence, there are only a few literatures that explain this phenomenon. Therefore, this article is made to explain the definition, effect, individual differences and theoretical model explaining relationship dissolution, especially in young adult woman ini Indonesia. Theoretical review is used to analyze one case of young adult woman in Jakarta seeking for professional help in a Psychology Clinic. Method used to analyze data is qualitative, phenomenology with Interpretative Phenomenological Analysis (IPA) technique. Data are gathered with semi structured, open-ended and non-directive questions. The result of this study is the respondent going through the process of "making-confiding account" and griefing process with the passing of counseling. Theoretical understanding of the implications of the breakup on the practice of clinical psychology will also be addressed in the discussion.
\end{abstract}

Keywords: relationship dissolution, relationship breakup, young adult

\begin{abstract}
ABSTRAK
Berakhirnya suatu hubungan intim merupakan peristiwa yang sering terjadi pada dewasa muda yang belum menikah. Walaupun begitu, masih sedikit literatur yang membahas hal ini secara khusus. Oleh karena itu, tulisan ini dibuat untuk menjabarkan definisi, dampak, perbedaan individu, serta model teoretis dalam menjelaskan pemutusan hubungan intim (relationship dissolution) khususnya pada wanita dewasa muda di Indonesia. Uraian teoretis ini digunakan untuk menganalisis satu kasus wanita dewasa muda di Jakarta yang mencari bantuan profesional di salah satu Klinik Psikologi. Metode yang digunakan ialah kualitatif dengan pendekatan fenomenologis, dengan teknik Interpretative Phenomenological Analysis (IPA) untuk menganalisis data. Metode pengumpulan data yang dipakai ialah wawancara semi-structured dengan pertanyaan open-ended dan non-directive. Hasil penelitian ini ialah responden melalui proses "account making-confiding" serta proses griefing seiring dengan berjalannya konseling. Implikasi pemahaman teoretis mengenai putus cinta pada praktik psikologi klinis juga akan dibahas dalam diskusi.
\end{abstract}

Kata kunci: relationship dissolution, putus cinta, patah hati, dewasa muda 


\section{PENDAHULUAN}

Masa dewasa muda adalah masa seseorang memiliki tugas perkembangan untuk membina hubungan intim dengan individu lain (Papalia, 2004). Hubungan intim terbangun dari interaksi dua orang yang saling memberi serta menerima melalui proses yang dinamis. Jadi, hubungan merupakan suatu proses yang penuh dengan perubahan, seperti perubahan mood hingga kondisi kesehatan (Miller, Perlman, Brehm, 2007). Perubahan dan evolusi yang terjadi dalam hubungan intim dapat saja sampai pada berakhirnya hubungan tersebut. Dari sudut pandang ini, maka pemutusan suatu hubungan (relationship dissolution) merupakan hal yang normal terjadi dalam dinamika hubungan intim (Duck \& Rollie, 2006). Dalam bahasa Indonesia sehari-hari, berakhirnya hubungan diberi label "putus cinta" atau sudah tidak mempunyai hubungan cinta lagi (KBBI). Putus cinta memiliki konotasi negatif dalam masyarakat, hal ini dapat dilihat dari lirik lagu yang mengaitkan putus cinta dengan pupusnya harapan seseorang dalam menjalani hidup.

Pemutusan hubungan intim ini menjadi topik bahasan yang penting dalam ilmu psikologi. Hal ini terlihat dari banyaknya penelitian mengenai pemutusan hubungan intim selama 10 tahun terakhir, misalnya mengenai proses dan dampak pemutusan hubungan intim pada keadaan emosi dan kepuasan menjalani hidup, kerentanan self-esteem, hingga gejala post-traumatic stress disorder (Priharani, 2004; Baker, 2006; Le, Dove, Agnew, Korn, Mutso, 2010; Slotter, Gardner, Finkel, 2010). Pentingnya topik ini untuk dibahas juga terlihat dari terbitnya "Handbook of Divorce and Relationship Dissolution" pada tahun 2006. Namun, penulis buku tersebut pun mengakui bahwa pembahasan mengenai pemutusan hubungan ini lebih banyak berfokus pada pemutusan hubungan pernikahan atau perceraian, karena dianggap memiliki dampak yang lebih intens (Harvey \& Weber, 2006).

Berdasarkan pengamatan penulis, dalam praktik sebagai psikolog klinis, dalam jangka waktu 8 bulan, sedikitnya 5 orang wanita dewasa muda datang ke klinik untuk mencari bantuan mengatasi dampak dari pemutusan hubungan romantis yang baru mereka alami. Dampak yang dirasakan antara lain perasaan sedih, kehampaan, perasaan gagal dan kehilangan kepercayaan diri, sulit berkonsentrasi, hingga timbul pikiran untuk bunuh diri. Hal ini menggambarkan bahwa pemutusan hubungan romantis pra-pernikahan juga memiliki dampak yang signifikan bagi dewasa muda, khususnya wanita. Walaupun demikian, penelitian mengenai pemutusan hubungan pra-pernikahan pada wanita dewasa muda, terutama di Indonesia masih relatif minim. Penelitian ini bertujuan untuk memahami gambaran dari proses putus cinta dalam hubungan pra-pernikahan yang dialami oleh wanita dewasa muda di Jakarta. Pemahaman ini diharapkan dapat membantu psikolog untuk membuat rancangan treatment bagi klien dengan kasus putus cinta, serta membantu keluarga memahami proses yang dialami oleh anak atau saudara yang mengalami putus cinta, sehingga bisa memberikan dukungan sosial yang tepat. Tulisan ini diawali tinjauan literatur mengenai putus cinta (relationship dissolution) pada wanita dewasa muda, mulai dari definisi, perbedaan individu dalam putus cinta serta beberapa model teoretis untuk menjelaskan putus cinta. Tinjauan literatur ini kemudian digunakan untuk menganalisis kasus putus cinta pada satu wanita dewasa muda di Jakarta.

\section{Putus Cinta (Relationship Dissolution)}

Dalam penelitian terdahulu, pemutusan hubungan intim antar-dua orang (relationship dissolution, atau disebut juga romantic break up) atau putus cinta dilihat sebagai suatu keadaan berakhirnya suatu ikatan emosional. Putus cinta dapat dilihat sebagai event maupun proses. Dalam penelitian awal tentang relationship dissolution, Bohannan (1988, dalam Duck \& Rollie, 2006) mendefinisikan perceraian (divorce) sebagai suatu proses ketimbang outcome dari hubungan. Ia membagi perceraian ke dalam enam posisi (stations) yang dialami individu. Posisi pertama ialah emotional divorce, yaitu sebagai suatu waktu waktu salah satu atau kedua belah pihak berpikir bahwa hubungan mereka telah berakhir. Pada tahap ini, individu menjadi ambivalen terhadap pasangannya, 
mulai berkembang secara terpisah baik dari segi psikologis, sosial dan emosional. Pada tahap ini, mereka mulai merasa tidak ada masa depan dalam hubungan tersebut dan mulai merasakan grief terkait dengan rasa kehilangan akan hubungan itu (Bohannan, 1968 dalam Duck \& Rollie, 2006). Tahap selanjutnya adalah legal divorce, economic divorce, co-parental divorce, community divorce, dan psychological divorce (Bohannan, 1968 dalam Duck \& Rollie, 2006). Pengertian emotional divorce di sini masih relevan untuk mendefinisikan keadaan putus cinta. Keenam tahap tersebut dilihat sebagai proses linear yang dialami satu individu, berlanjut dari satu tahap ke tahap selanjutnya secara berurut. Dalam perkembangannya, putus dilihat lebih sebagai proses yang lebih menekankan mengenai aspek relasional dalam putus cinta, ketimbang mendeskripsikan tahap-tahap yang terjadi dalam putus cinta pada satu individu.

\section{Proses Putus Cinta (relationship dissolution process)}

Peristiwa putus cinta merupakan peristiwa yang khas (idiosyncratic) pada orang yang mengalami. Namun Steve Duck (1982 dalam Miller, Perlman, Brehm, 2007) mengajukan sebuah tahap-tahap umum yang terjadi dalam pemutusan hubungan intim. Tahap pertama ialah personal phase, yaitu salah satu pihak merasa tidak puas, frustasi dan marah. Selanjutnya ialah dyadic phase, yaitu pihak yang tidak bahagia mengungkapkan ketidakpuasannya. Tahap ini berisi periode negosiasi, konfrontasi serta usaha mengakomodasi keluhan salah satu pihak, sehingga sering disertai perasaan shock, marah, terluka, dan terkadang ada perasaan lega. Semakin dekat ke akhir hubungan, tahap yang terjadi ialah social phase, yakni kedua belah pihak mulai mengungkapkan cerita versi masing-masing mengenai kesulitan dalam hubungan kepada teman dan keluarga, untuk mencari dukungan dan untuk dimengerti. Tahap terakhir, terjadi setelah hubungan diakhiri, yaitu grave-dressing phase. Dalam tahap ini, seseorang mulai berusaha mengatasi rasa kehilangan dengan merevisi memori, atau membuat cerita yang dapat diterima (account making).

Seiring dengan perkembangan penelitian mengenai pemutusan hubungan intim, Duck (2005 dalam Duck \& Rollie, 2006) merevisi tahapan tersebut dan mengganti kata tahapan dengan "proses". Pada model yang lebih baru, pemutusan hubungan tidak lagi dilihat sebagai tahapan yang linear, tetapi merupakan proses yang berkelanjutan dan 'naik-turun'. Bahkan, proses pemutusan hubungan sering kali sudah dimulai tanpa pasangan menyadari bahwa mereka sedang berada dalam proses tersebut. Model proses pemutusan hubungan yang baru ini menjelaskan bahwa retaknya suatu hubungan terjadi dalam proses yang dialami pasangan dalam kehidupan mereka sehari-hari. Oleh karena itu, saat pasangan mulai merasa tidak puas dalam hubungan dan mulai mencari dukungan sosial, ia tidak melihat bahwa dirinya sedang memasuki tahap social phase yang dijelaskan di atas. Mereka melihat upaya mencari dukungan sosial sebagai upaya memperbaiki hubungan. Modifikasi lain dari model Duck (1982, dalam Duck \& Rollie, 2006) ialah pada tahap grave-dressing phase, seseorang tidak hanya mempersiapkan dirinya keluar dari suatu hubungan, tetapi juga menyiapkan diri mereka untuk suatu hubungan baru. Mereka berhadapan dengan isu-isu seperti self-esteem, self image, expectations, self-goals, tidak hanya masalah-masalah kelekatan emosi dengan mantan pasangan. Oleh karena itu, Duck (2005, dalam Duck \& Rollie, 2006) menambahkan tahap resurrection dari empat tahapan yang sudah ada. Model yang lebih baru juga menambahkan adanya proses evaluasi diri yang berada di antara tiap fase. Evaluasi diri ini terkait dengan perbedaan individu dalam mengalami efek putus cinta, yang akan dijelaskan selanjutnya. 
Tabel 1 Perbedaan Fase dan Proses Pemutusan Hubungan

\begin{tabular}{ll}
\multicolumn{1}{c}{$\begin{array}{c}\text { Relationship Dissolution Phase } \\
\text { (Duck, 1982 dalam Miller, Perlman, Brehm, 2007) }\end{array}$} & $\begin{array}{c}\text { Relationship Dissolution Process } \\
\text { (Ducks, 2005 dalam Duck \& Rollie, 2006) }\end{array}$ \\
\hline $\begin{array}{l}\text { Pemutusan hubungan digambarkan sebagai tahapan } \\
\text { yang linear. }\end{array}$ & $\begin{array}{l}\text { Pemutusan hubungan digambarkan sebagai } \\
\text { proses yang naik-turun. }\end{array}$ \\
$\begin{array}{l}\text { Terdapat } 4 \text { fase: personal, dyadic, social, grave- } \\
\text { dressing. }\end{array}$ & $\begin{array}{l}\text { Proses terdiri dari: proses personal, dyadic, } \\
\text { social, grave-dressing, resurrection. }\end{array}$ \\
Terdapat perbedaan yang jelas antar fase. & $\begin{array}{l}\text { Fase dilihat lebih sebagai pola dalam suatu } \\
\text { proses yang berkesinambungan, tiap proses } \\
\text { diantarai dengan evaluasi diri. }\end{array}$ \\
& $\begin{array}{l}\text { Menambahkan aspek relasional dan komunikasi } \\
\text { antar pasangan. }\end{array}$ \\
\hline
\end{tabular}

\section{Dampak dan Perbedaan Individu dalam Putus Cinta}

Pemutusan hubungan romantis atau putus cinta memiliki dampak dan reaksi yang beragam pada individu, baik dalam segi emosi, perilaku maupun kognitif. Penelitian memperlihatkan bahwa setelah putus cinta, seseorang merasakan emosi negatif seperti sedih dan kurang merasakan cinta (Sbarra \& Emery, 2005), marah, sakit, frustasi, kebencian, kesepian, depresi (Frazier \& Cook, 1993; Sprecher, 1994, dalam Park, Sanchez \& Brynildsen, 2011), menurunnya kepuasan dalam menjalani hidup (Rhoades, Kamp, Atkins, Stanley, Markman, 2011) hingga gejala post-traumatic stress (Chung et. all, 2002). Putus cinta juga terkait dengan kerentanan pada konsep diri (Slotter \& Gardner, 2010) dan self-esteem (Park \& Sanchez, 2011). Di Amerika, putus cinta bahkan terkait dengan perilaku harassing dan stalking mantan kekasih untuk mengatasi rasa kehilangan (Cupach, \& Spitzberg, 2004, dalam Park \& Sanchez, 2011).

Selain itu, perasaan sakit serta keadaan emosional-kognitif yang dialami pasca putus cinta juga dapat dijelaskan secara neurologis, bagian otak yang aktif saat patah hati sama seperti bagian otak yang aktif saat merasakan sakit fisik, seperti terkena air panas (Kross, Mischel, Wager, Smith, 2011) serta bagian otak yang aktif pada pengguna coccaine pada masa withdrawal (Fisher, Brown, Strong, Mashek, 2010).

Walaupun begitu, dampak serta reaksi terhadap putus cinta yang dijelaskan di atas, dialami secara berbeda oleh masing-masing individu. Faktor-faktor perbedaan individu yang terkait dengan reaksi terhadap putus cinta antara lain: cara seseorang menggantungkan self-worth, attachment style, jenis kelamin (Field et al., 2004 Duck \& Wood, 2006; Park \& Sanchez, 2011), posisi dalam pemutusan hubungan, yaitu pihak yang memutuskan, atau yang diputuskan (Park \& Sanchez, 2011), serta karakteristik hubungan sebelum pemutusan terjadi (Rhoades, Kamp, Atkins, Stanley, Markman, 2011). Wanita cenderung memiliki distress pasca putus yang lebih besar dibandingan dengan pria (Field et al., 2004). Pasangan yang telah tinggal bersama dan memiliki rencana untuk menikah memiliki penurunan kepuasan hidup yang lebih tinggi dibandingkan pasangan lain, sedangkan kualitas hubungan yang tinggi sebelum putus terkait dengan penurunan kepuasan hidup yang lebih sedikit dibandingkan kualitas hubungan yang buruk sebelum putus (Rhoades, Kamp, Atkins, Stanley, Markman, 2011).

\section{Model Teoretis 1: Putus Cinta dan Proses Berduka (grief)}

Seperti yang sudah dijelaskan di atas, pemutusan hubungan intim terkait dengan grief dan rasa kehilangan akan dukungan emosional yang didapat dari hubungan. Oleh karena itu, proses putus cinta 
juga dapat ditinjau dari proses grieving. Salah satu teori yang populer dalam menjelaskan proses grieving adalah tahapan dari Kubler-Ross (Priharani, 2004). Kubler-Ross (1998) menjelaskan tahaptahap grieving sebagai berikut. Tahap pertama ialah penyangkalan (denial), saat seseorang akan menyangkal bahwa hubungannya sudah berakhir. Selanjutnya ialah tahap marah (anger), ketika penyangkalan sudah tidak tertahankan, akan digantikan dengan rasa marah, gusar, cemburu dan benci. Timbul pertanyaan "kenapa aku?" dan mudah tersinggung oleh perilaku orang lain di sekitarnya. Tahap ketiga ialah tawar-menawar (bargaining). Pada tahap ini, seseorang meninggalkan kemarahan dan menggantinya dengan strategi lain, yaitu dengan menukar perilaku baik dengan keadaan yang baik. Bentuk menawar biasanya merupakan perjanjian dengan Tuhan. Selanjutnya ialah tahap depresi, saat seseorang sudah menyadari bahwa tidak ada yang dapat dilakukan untuk menghindari pemutusan hubungan yang terjadi. Kesadaran ini biasanya diikuti dengan bukti-bukti bahwa hubungan tidak dapat diselamatkan. Pada tahap ini biasanya seseorang merasa sulit makan, sulit memusatkan perhatian dan menghindari situasi yang tidak nyaman. Tahap terakhir ialah penerimaan (acceptance), ketika terlalu lemah untuk marah dan sudah terbiasa dengan pikiran mengenai patah hati sehingga tidak merasa depresi. Pada tahap ini seseorang merasa damai dan menggunakan waktunya untuk berbagai kegiatan baru. Tahapan-tahapan ini tidak selalu dialami secara berurutan. Beberapa orang tidak pernah mengalami tahap tertentu. Semua perasaan yang berkaitan dengan kelima tahap tersebut dapat dialami secara berganti-ganti, misalnya seorang yang sedang marah juga dapat mengalami penyangkalan.

\section{Model Teoretis 2: Putus Cinta dan Account Making-Confiding Process}

Model teoretis lain untuk menjelaskan bagaimana terjadinya putus cinta serta apa kelanjutan dari putus cinta ialah account making-confiding model dari Harvey \& Weber (2001, dalam Priharani, 2004; 1994, dalam Miller, Perlman, Brehm, 2007). Account dalam teori ini mengacu pada deskripsi naratif akan peristiwa putus cinta yang terjadi, atau penjelasan mengenai pengalaman seseorang dengan menekankan pada karakter dan kejadian yang mengakibatkan peristiwa tersebut (Weber, 1992, dalam Miller, Perlman, Brehm, 2007).

Proses account making-confiding ini terdiri dari proses sense-making. Seseorang berusaha mencari makna dan membentuk alur cerita (terdiri dari pemahaman tentang proses awal, pertengahan, akhir) sehubungan dengan peristiwa kehilangan atau pemutusan hubungan percintaan yang sepihak. Contoh pertanyaan yang sering muncul “mengapa dan bagaimana semua ini bisa terjadi pada saya?”. Tahap selanjutnya ialah benefit-finding: seseorang berusaha mencari hikmah spiritualitas dan pelajaran positif dari peristiwa kehilangan. Contoh pertanyaan yang sering muncul: "Apa sebenarnya rencana Tuhan di balik semua kesedihan dan kesulitan ini?”. Selanjutnya ialah tahap identity reconstruction, seseorang berusaha lebih memahami diri, membentuk identitas diri yang kuat, membangun semangat dan harapan baru untuk hidup selanjutnya. Contoh pertanyaan: "apa yang harus saya lakukan sekarang?”, “apa tujuan hidup saya selanjutnya?”. Seiring dengan proses di atas, seseorang perlu melakukan aktivitas confiding, yaitu proses berbagi cerita dengan orang terdekat yang dapat dipercaya sambil berusaha memahami alur cerita dari pengalamannya serta mencari validasai terhadap pikiran dan perasaannya. Melalui aktivitas confinding ini, seseorang memulai kembali interaksi dengan orang sekitarnya: teman, sahabat, orangtua, atau profesional seperti psikolog. Dampak confinding ini hanya akan positif jika orang yang diajak berbagi memiliki rasa empati (Harvey \& Weber, 2001, dalam Priharani, 2004).

Dari penjelasan di atas, dapat dilihat bahwa proses account berfungsi untuk mempertahankan self-esteem, memengaruhi bagaimana orang lain berpikir tentang diri seseorang, serta berbagi cerita dengan orang lain. Selain itu, membuat narasi mengenai perstiwa yang terjadi akan membantu seseorang menemukan makna dari peristiwa tersebut. Bahkan proses account yang dilakukan dengan sungguh-sungguh dapat memfasilitasi kesejahteraan psikologis, empati, serta penting dalam proses pemulihan dari rasa kehilangan akan suatu hubungan (Weber \& Harve, 1994, dalam Miller, Perlman, Brehm, 2007). 


\section{METODE PENELITIAN}

Tulisan ini dirangkai dengan mengumpulkan dan menelaah buku teks dan jurnal dari data base online, yaitu Proquest, EBSCO, serta Google Scholar dengan memasukkan kata kunci "relationship dissolution", "romantic dissolution", serta "relationship break-up". Teori ini kemudian digunakan untuk menganalisis temuan penelitian kualitatif, dengan pendekatan fenomenologis. Metode analisis data yang dipakai adalah Interpretative Phenomenological Analysis (IPA). Tujuan dari IPA ialah menangkap kualitas dan tekstur dari pengalaman individu. Dalam melakukan penelitian dengan metode interpretative analysis phenomenology, peneliti dapat menentukan tema apa saja yang relevan dan yang tidak relevan dalam fenomena yang sedang diteliti. IPA menggunakan pendekatan ideografis yang bertujuan memahami kasus secara detail dan mendalam. Pembahasan difokuskan pada pemutusan hubungan pra-pernikahan pada masa dewasa muda, khususnya pada wanita dewasa muda di Jakarta.

Partisipan penelitian ini ialah satu orang wanita dewasa muda usia 24 tahun yang mengalami pemutusan hubungan romantis setelah 5 tahun berpacaran dan sudah berencana untuk menikah. Wawancara dilakukan dalam setting konseling psikologis, selama tiga kali, yaitu pada 6 \& 13 Agustus 2012 serta 10 September 2012, dengan peneliti sebagai psikolog. Selanjutnya Partisipan akan disebut dengan "Ami”.

\section{HASIL DAN PEMBAHASAN}

Berdasarkan hasil wawancara selama tiga pertemuan konseling, maka gambaran proses putus cinta yang dialami oleh Ami dapat diringkas dalam tabel berikut.

Tabel 2 Ringkasan Hasil Wawancara

\begin{tabular}{lll}
$\begin{array}{c}\text { Proses Grieving } \\
\text { (Kubler-Ross, 1998) }\end{array}$ & $\begin{array}{c}\text { Account Making-Confiding Process } \\
\text { (Harvey \& Weber, 2001, dalam } \\
\text { Miller, Perlman, Brehm, 2007) }\end{array}$ & \multicolumn{1}{c}{ Pengalaman Ami } \\
\hline Penyangkalan & Sense-making Confiding & $\begin{array}{l}\text { Observasi: Pertemuan pertama, Ami datang } \\
\text { ke konseling dengan wajah muram dan } \\
\text { menangis saat bercerita. }\end{array}$ \\
& $\begin{array}{l}\text { Ringkasan Wawancara: Ami merasa sedih } \\
\text { dan putus asa karena baru putus dari }\end{array}$ \\
& $\begin{array}{l}\text { pacarnya setelah 5 tahun berhubungan. la } \\
\text { merasa bersalah dan melihat dirinya sebagai }\end{array}$ \\
& $\begin{array}{l}\text { sumber kegagalan hubungannya karena ia } \\
\text { diputuskan oleh pacarnya saat sedang }\end{array}$ \\
& $\begin{array}{l}\text { membicarakan mengenai persiapan } \\
\text { pernikahan. la masih berusaha menghubungi } \\
\text { pacarnya dan berharap hubungan mereka } \\
\text { dapat dilanjutkan, tapi tidak direspon. }\end{array}$ \\
\hline Marah & $\begin{array}{l}\text { Observasi: Ami berbicara dengan cepat dan } \\
\text { tampak gusar, dengan mata berkaca-kaca. }\end{array}$ \\
& $\begin{array}{l}\text { Ringkasan wawancara: Ami merasa marah } \\
\text { dan kecewa pada dirinya sendiri. la merasa }\end{array}$ \\
& gagal dan belum dewasa. Selain itu, ia lebih \\
& mudah tersinggung oleh ibu dan kakak \\
\hline
\end{tabular}




\begin{tabular}{|c|c|c|}
\hline & & $\begin{array}{l}\text { perempuannya yang seringkali } \\
\text { mengingatkannya pada mantan pacar. }\end{array}$ \\
\hline Tawar-menawar & & $\begin{array}{l}\text { Ringkasan wawancara: Timbul pikiran "kalau } \\
\text { saja saya lebih dewasa dalam } \\
\text { menghadapinya". }\end{array}$ \\
\hline Depresi & $\begin{array}{l}\text { Benefit } \\
\text { finding }\end{array}$ & $\begin{array}{l}\text { Ringkasan wawancara: Ami merasa dirinya } \\
\text { gagal, tidak dewasa dan akan gagal juga } \\
\text { dalam kuliah magister yang sedang } \\
\text { dijalaninya. la merasa kehilangan bagian dari } \\
\text { diri dan pendukung utama dalam hidup. la } \\
\text { berusaha berdoa dan mencari tahu maksud } \\
\text { Tuhan akan apa yang dialaminya. }\end{array}$ \\
\hline Penerimaan & $\begin{array}{ll}\text { Identity } & \text { Confiding } \\
\text { reconstruction } & \end{array}$ & $\begin{array}{l}\text { Observasi: Pertemuan ke-3 (jarak } 1 \text { bulan } \\
\text { dari pertemuan sebelumnya) Ami datang } \\
\text { dengan raut wajah cerah, lebih banyak } \\
\text { tersenyum. } \\
\text { Ringkasan wawancara: la baru saja } \\
\text { mendengar bahwa mantan pacarnya sudah } \\
\text { dekat dengan perempuan lain. la mendapat } \\
\text { kabar ini dari tetangganya. la pun melihat } \\
\text { pengalaman ini sebagai tanda dari Tuhan } \\
\text { bahwa bukan ia yang bersalah dalam } \\
\text { berakhirnya hubungan dengan mantan pacar. } \\
\text { la merasa lega dan lebih bisa menerima } \\
\text { keadaan dirinya saat ini dan ingin mencoba } \\
\text { menjalin pertemanan dekat dengan laki-laki } \\
\text { lain. la juga melaporkan frekuensi menangis } \\
\text { yang berkurang drastis. la pun mencoba lebih } \\
\text { terbuka dalam menceritakan pengalamannya } \\
\text { pada kakak perempuan dan ibunya. }\end{array}$ \\
\hline
\end{tabular}

Dari tabel di atas terlihat bahwa pengalaman Ami dapat dianalisis dengan melihat proses grieving maupun account making-confiding process. Kedatangan Ami ke psikolog merupakan salah satu usaha melakukan confiding. Hal ini karena ia memiliki hubungan yang kurang baik dengan saudara perempuan dan ibunya. Proses confiding terjadi di semua tahap pada proses account makingconfiding process. Dari pengalaman Ami, dapat dilihat bahwa perasaan sedih, gagal, serta putus asa akibat pemutusan hubungan pra-nikah dapat berakhir dengan perasaan lega serta rasa percaya diri yang lebih dibandingkan masa awal putus hubungan. Salah satu hal yang berperan dalam proses ini ialah usaha Ami datang ke psikolog untuk melakukan confiding dengan profesional.

\section{SIMPULAN}

Berdasarkan uraian di atas, maka dapat dilihat bahwa putus cinta merupakan suatu proses yang wajar dari sebuah hubungan intim. Walaupun bahasa yang dipakai untuk menggambarkan proses ini mengesankan suatu hubungan berakhir atau putus, dilihat dari proses yang terjadi, hubungan antar-dua orang tidaklah sepenuhnya berakhir. Melainkan terbentuk hubungan baru dengan 'aturan main' yang baru pula.

Berakhirnya suatu hubungan memang memiliki dampak yang negatif baik dari sisi emosi, perilaku maupun kognisi. Namun, kedua model teoretis yang telah dijabarkan, melihat putus cinta 
sebagai proses yang berunjung pada penerimaan atau pembentukan cerita (account) yang pada akhirnya membantu individu untuk melanjutkan hidupnya dan membentuk hubungan intim baru dengan orang lain. Pandangan ini bertolak belakang dengan pandangan awam yang mengaitkan putus cinta dengan berakhirnya kehidupan seseorang. Oleh karena itu, perlu diteliti lebih lanjut mengenai dampak lagu-lagu 'putus cinta' yang bertemakan "berakhirnya hidup” pada proses pemulihan seseorang pasca putus cinta. Selain itu, model account making-confiding juga memberikan alternatif cara untuk membantu proses pemulihan seseorang pasca putus. Seperti pada contoh kasus “Ami”, ia melakukan confiding dengan menceritakan permasalahan serta perasaan pasca putus ke psikolog, sehingga pada akhirnya ia merasa lebih lega dan mulai berpikir untuk memulai hubungan baru dengan laki-laki lain. Hasil penelitian ini belum dapat digeneralisasi, karena hanya berdasarkan pada satu kasus. Untuk penelitian selanjutnya dapat melihat dampak aktivitas confiding pada proses pemulihan pascaputus dari hubungan romantis. Selain itu, penelitian ini hanya mengambil wanita dewasa muda sebagai responden. Untuk penelitian selanjutnya dapat diteliti juga mengenai proses putus hubungan pada laki-laki.

\section{DAFTAR PUSTAKA}

Baker, R.B. (2006). Romantic dissolution and social suppot during adolescents' transition to college. Bowling Green State University. Tesis: Tidak diterbitkan.

Duck, S; Rollie, S.S. (2006). Divorce and Dissolution of Romantic Relationships: Stage Models and Their Limitations. Dalam Fine, Mark A. (Ed); Harvey, John H. (Ed), (2006). Handbook of divorce and relationship dissolution., (pp. 223-240). Mahwah, NJ, US: Lawrence Erlbaum Associates.

Duck, S; Wood, J. T. (2006) What Goes Up May Come Down: Sex and Gendered Patterns in Relational Dissolution. Dalam Fine, Mark A. (Ed); Harvey, John H. (Ed), (2006). Handbook of divorce and relationship dissolution., (pp. 169-187). Mahwah, NJ, US: Lawrence Erlbaum Associates.

Field, T., Diego, M., Pelaez, M., Deeds, O., Delgado, J. (2009). Breakup distress in university students. Adolescence; Winter 2009; Vol. 44, No. 176, 705-727.

Fisher, H. E., Brown, L. L., Aron, A., Strong, G., Mashek, D. 2010. Reward, addiction, and emotion regulation systems associated with rejection in love. J Neurophysiol (May 5, 2010).

Kross, E., Berman, M. G., Mischel, W., Smith, E. E., Wager, T. D. (2011). Social rejection shares somatosensory representations with physical pain. PNAS (April 12, 2011, vol. 108, no. 15).

Kubler, Ross. (1998) Kematian sebagai bagian kehidupan (on death and dying). Jakarta: Gramedia Pustaka Utama.

Le, B., Dove, N., Agnew, C.R., Korn, M.S., Mutso, A.A. (2010). Predicting nonmarital romantic relationship dissolution: A meta-analytic synthesis. Personal Relationships, vol. 17 pp. 377390.

Papalia, D. E., Olds, S. E., Feldman, R. D. (2004). Human Development: 9th ed. New York: McGrawHill. 
Park, L. E., Sanchez, D. T., \& Brynildsen, K. (2011). Maladaptive responses to romantic breakup: The role of relationship contingent self-worth. Journal of Applied Social Psychology Vol. 41, Issue 7, pg. 1749-1773, July 2011.

Priharani, U. A. 2004. Gambaran Proses Grieving dan Cara Coping pada orang dewasa muda yang mengalami putus cinta. Depok: Skripsi (tidak diterbitkan).

Rhoades, G.K., Kamp Dush, C.M., Atkins, D.C., Stanley, S.M., Markman, H.I. (2011). Breaking up is hard to do: the impact of unmarried relationship dissolution on mental health and life satisfaction. University of Denver, diunduh dari http://www.ncbi.nlm.nih.gov/pubmed/21517174

Sbarra, D.A. (2006). Predicting the onset of emotional recovery following nonmarital relationship dissolution: survival analyses of sadness and anger. Personality and Social Psychology Bulletin, Vol. 32, No. 3, 298-312.

Sbarra, D.A., Emery, R.E. (2005). The emotional sequelae of bibmarital relationship dissolution: Analysis of change and intraindividual variability over time. Personal Relationship, Vol. 12, 213-232.

Slotter, E.B., Gardner, W.L. (2010). Who am I without you? The influence of romantic breakup on the self-concept. Personality and Social Psychology Bulletin, Vol. 36, No. 2, 147-160. 